\title{
Organic Pollutant Contamination of the River Elbe as Assessed by Biochemical Markers
}

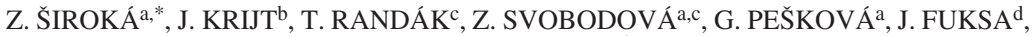 \\ J. HAJŠLOVÁ ${ }^{\mathrm{e}}$, J. JARKOVSKÝf ${ }^{\mathrm{f}}$, M. JÁNSKÁ ${ }^{\mathrm{e}}$ \\ aUniversity of Veterinary and Pharmaceutical Sciences Brno, Faculty of Veterinary Hygiene and Ecology, \\ Palackeho 1-3, 61242 Brno, Czech Republic \\ ${ }^{\mathrm{b}}$ Charles University, 1st Faculty of Medicine, Institute of Pathological Physiology, U nemocnice 5, \\ 12853 Praha 2, Czech Republic \\ ${ }^{\mathrm{c}}$ University of South Bohemia Ceske Budejovice, Research Institute of Fish Culture and Hydrobiology \\ Vodnany, Zatisi 728/II, 38925 Vodnany, Czech Republic \\ dT.G.M. Water Research Institute, Podbabska 30, 16062 Praha 6, Czech Republic \\ eInstitute of Chemical Technology Prague, Department of Food Chemistry and Analysis, Technicka 3 , \\ 16628 Praha 6, Czech Republic \\ ${ }^{\mathrm{f}}$ Masaryk University Brno, Faculty of Science, Centre of Biostatistics and Analyses, Kamenice 126/3, \\ 62500 Brno, Czech Republic
}

Received June 28, 2004

Accepted March 3, 2005

\begin{abstract}
Široká Z., J. Krijt, T. Randák, Z. Svobodová, G. Pešková, J. Fuksa, J. Hajšlová, J. Jarkovský, M. Jánská: Organic Pollutant Contamination of the River Elbe as Assessed by Biochemical Markers. Acta Vet Brno 2005, 74: 293-303.

The aim of the study was to assess contamination of the River Elbe basin using selected biochemical markers. Biochemical markers selected were enzymes of the first stage of xenobiotic transformation, namely cytochrome P450 (CYP 450) and ethoxyresorufin-O-deethylase (EROD). The results were correlated with the most important inducers of the enzymes, i.e. polychlorinated biphenyls (PCB) concentrations in muscle tissue of fish, polyaromatic hydrocarbons (PAH) values in bottom sediments and 1-hydroxypyrene (1-OHPY) values in fish bile (terminal metabolite of $\mathrm{PAH}$, or, rather, of one of them, i.e. pyrene), which were determined during the chemical monitoring of the River Elbe basin. The indicator species selected was chub (Leuciscus cephalus L.), which was captured at ten locations in the River Elbe basin. A comparison between the EROD activity and the CYP 450 content along the longitudinal profile of the Elbe showed a significant correlation at the level of significance of $p<0.05$. The highest EROD activity levels in the liver were ascertained in Zelčín $\left(341 \mathrm{pmol} \cdot \mathrm{min}^{-1} \cdot \mathrm{mg}^{-1}\right)$, Valy $\left(263.2 \mathrm{pmol} \cdot \mathrm{min}^{-1} \cdot \mathrm{mg}^{-1}\right)$ and Lysá nad Labem (179.17 $\left.\mathrm{pmol} \cdot \mathrm{min}^{-1} \cdot \mathrm{mg}^{-1}\right)$. In Blanice (control location), EROD activity was significantly lower than in any of the other locations studied $(p<0.05)$. The study failed to produce an unambiguous proof of any correlations between detoxification enzyme activity (CYP 450 and EROD) in the liver and their two important inducers (PCB and PAHs). The possibility that other substances causing activation or inhibition of detoxification enzymes were in play is also discussed.
\end{abstract}

Cytochrome P450, EROD, Leuciscus cephalus L., liver, PCB, PAH, 1-hydroxypyrene

The River Elbe is one of the most important European rivers (total length $1103.5 \mathrm{~km}$ ). Its extensive basin of a total of $148268 \mathrm{~km}^{2}$ lies on the territory of two countries, i.e. the Czech Republic $\left(51336 \mathrm{~km}^{2}\right)$ and Germany $\left(96932 \mathrm{~km}^{2}\right)$. Intensive research of the Czech and German reaches of the Elbe started in 1991 under the Elbe I (1991 - 1994) project, and continued with the Elbe II (1995 - 1998) and Elbe III (1999 - 2002) projects. In those projects, large quantities of data regarding sources of pollution, chemical monitoring of hazardous substances in various components of the aquatic environment, water quality, etc. were collected and evaluated (Nes měrák 1994; B lažk ová et al. 1998; B lažk ová 2002). To enhance the relevance of results obtained by chemical monitoring, it is, however, also

Address for correspondence:

Široká Zuzana

Department of Public Veterinary Health and Toxicology

University of Veterinary and Pharmaceutical Sciences Brno

Palackého 1-3, 61242 Brno, Czech Republic

Phone: +420 541562780

E-mail: sirokaz@vfu.cz

http://www.vfu.cz/acta-vet/actavet.htm 
necessary to assess the effects of anthropogenic pollution of the aquatic environment on fish. One of possible ways of assessing such effects is the use of biochemical markers of contamination. They are measurable biochemical parameters responding usually to substances with the same mechanism of toxic effect. That means they are not, with some exceptions, specific for individual xenobiotic substances. Their advantage lies in their ability to provide comprehensive information on the effects of pollution, i.e. to reflect synergic or antagonistic effects of individual components contributing to pollution.

In 2003, the Elbe IV Project was started. For reasons mentioned above, chemical monitoring in fish was complemented with assay of biochemical contamination markers. Attention focused primarily on the enzymes of the first phase of xenobiotics conversion, i.e. cytochrome P450 and ethoxyresorufin-O-deethylase (EROD).

Cytochrome P450 is an important biochemical marker of surface water contamination with some industrial and agricultural pollutants (Stegeman and Lech 1991). It is now believed that the most useful is the 1A family of cytochrome P450 (Machala et al. 1997; Schlenk and Di Giulio 2002). The most potent inducers for that isoform are substances from the groups of polychlorinated biphenyls (PCB), polycyclic aromatic hydrocarbons (PAH), nitrated polycyclic aromatic hydrocarbons (NPAH) and dioxins (e.g. 2, 3, 7, 8 TCDD) (White et al. 1997; Nilsen et al. 1998; Jung et al. 2001; Schlenk and Di Giulio 2002). On the other hand, chronic exposure to these contaminants can cause a lack of CYP1A induction response (Brammell et al. 2004), and also assessment of CYP1A at the time of spawning can influence its level, because estrogens can decrease CYP1A induction (Elskus 2004). Male fish seem to be more sensitive to PAH and PCB than female fish (McArdle et al. 2004). The induction of the CYP1A family is mediated by the aryl hydrocarbon receptor (AhR) (Billiard 2002). Following its interaction with xenobiotic substances, it is carried to the nucleus where it is the cause of enhanced expression of genes for CYP1A and, subsequently, of increased synthesis of cytochrome proteins. The potential toxicity of pollutants depends on their affinity to the AhR. The CYP1As are also responsible for the metabolic activation of most of the known promutagens and procarcinogens, and its elevated levels are responsible for such negative effects as cocarcinogenesis, immunotoxicity and reproduction disorders (Lew is et al. 2003; Carls on et al. 2004). The model CYP1A activity is the enzyme ethoxyresorufin-O-deethylase (EROD), with its ability to convert substrates to products demonstrating fluorescence, which can then be measured. This enzyme is an important biochemical marker of contamination.

The aim of the study presented here was to use the assessment of biochemical markers cytochrome P450 and EROD in the livers of the indicator fish species (Leuciscus cephalus L.) to evaluate contamination levels in various locations within the River Elbe basin. Results of chemical monitoring relevant for the above contamination markers are also outlined and correlated in the paper. They were PCB concentrations in chub muscle tissues, concentrations of 1-hydroxypyrene (1-OHPY) in chub bile samples (i.e. the final metabolite of PAHs, or rather of pyrene), and PAH concentrations in bottom sediments in the locations studied.

\section{Materials and Methods}

Animals and Sampling

The chub (Leuciscus cephalus L.) was selected as the most suitable indicator species. The chub is a common freshwater cyprinid species that inhabits both clean and polluted rivers (B aruš et al. 1995). The fish were captured with the use of a diesel-electric generator in 10 locations in the River Elbe basin. The locations studied were Podolí and Zelčín at the River Vltava, a tributary to the Elbe, and Verdek, Němčice, Valy, Lysá nad Labem, Obříství, Děčín and Hřensko along the River Elbe. The control location was upstream of the Husinec water reservoir at the river Blanice in the Vltava basin (Fig. 1). The fish were captured in July 2003 (average water temperature $21.4{ }^{\circ} \mathrm{C}$ ). In the control location, fish were captured in September 2003 (water temperature $15^{\circ} \mathrm{C}$ ). In each location, eight chub (both males and females) were captured (except in Lysá nad Labem where only 3 chub were captured). The chub 
were weighed and their scales collected for age determination. The characteristics of fish captured in individual locations are summarized in Table 1.

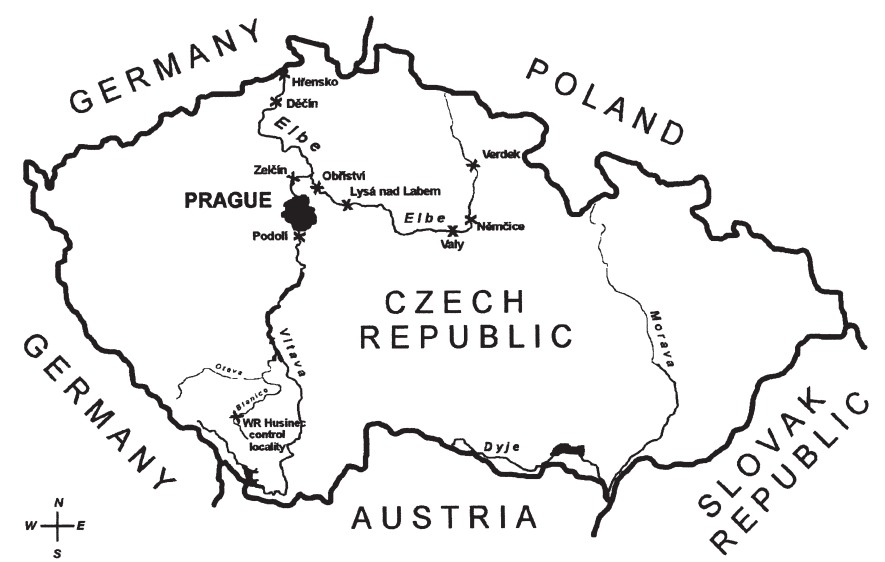

Fig. 1.The Elbe basin locations studied.

Table 1. Characteristics of chub (Leuciscus cephalus L.) captured in individual locations in the River Elbe basin.

\begin{tabular}{|lcc|}
\hline Location & weight $\pm \mathrm{SD}(\mathrm{g})$ & age $(\mathrm{yrs})(\min -\max )$ \\
\hline Blanice & $202.5 \pm 45.18$ & $3.3(3-4)$ \\
\hline Podolí - Vltava & $243.0 \pm 74.94$ & $3.9(3-5)$ \\
\hline Zelčín - Vltava & $591.5 \pm 353.68$ & $5.1(2-8)$ \\
\hline Verdek - Elbe & $366.67 \pm 150.06$ & $3.9(3-5)$ \\
\hline Němčice - Elbe & $628.0 \pm 326.99$ & $6.1(3-8)$ \\
\hline Valy - Elbe & $315.0 \pm 85.41$ & $3.4(3-4)$ \\
\hline Lysá nad Labem - Elbe & $375.0 \pm 242.62$ & $4.3(3-6)$ \\
\hline Obř́ství - Elbe & $892.5 \pm 377.47$ & $7.1(4-9)$ \\
\hline Děčín - Elbe & $521.0 \pm 207.18$ & $5.4(3-7)$ \\
\hline Hř́nsko - Elbe & $394.5 \pm 130.60$ & $4.5(3-6)$ \\
\hline
\end{tabular}

Liver tissue samples of $0.1-1.0 \mathrm{~g}$ were collected from each chub for the cytochrome P450 and EROD assays. Bile samples were collected for 1-hydroxypyrene assays. Liver and bile samples were immediately frozen in liquid nitrogen and stored at $-80{ }^{\circ} \mathrm{C}$ until enzymatic assays were performed. Composite muscle samples were collected for PCB chemical analysis. In the same locations in the Elbe basin, bottom sediment samples were collected for the determination of polycyclic aromatic hydrocarbons (PAH). Metal pipes (probes) were employed to collect specimens of inconsistent sediments along riverbanks at the depth of $0.1-0.5 \mathrm{~m}$. After particles bigger than 0.5 $\mathrm{mm}$ were removed from them, samples were transported in refrigerate container to the laboratory and stored there at $-20^{\circ} \mathrm{C}$. A recent flood made the collection of any comparable sediment samples in the Děčín profile impossible. In Blanice, sediment contained mainly sand and gravel with very little organic detritus.

Determination of cytochrome P450 and EROD in liver tissue samples

Before the analysis, liver tissue samples were taken out of the freezing box and placed on ice to thaw. Buffer was added to samples $(15 \mathrm{ml}$ of $1.15 \% \mathrm{KCl})$ and they were then homogenized. Homogenized samples were placed to centrifuging tubes and centrifuged at $11100 \mathrm{rpm}(10000 \mathrm{~g})$ for $20 \mathrm{~min}$ at $4{ }^{\circ} \mathrm{C}$. The pellets then contained the remains of non-homogenized liver tissue and mitochondria, and the supernatant contained cytosol and other hepatocyte organelles. The supernatant $(12 \mathrm{ml})$ was carefully pipetted (to prevent any damage to the pellet or the phospholipid layer floating on the surface) to ultracentrifugation tubes, where it was re-centrifuged at $37800 \mathrm{rpm}$ $(100000 \mathrm{~g})$ for $1 \mathrm{~h}$ at $4{ }^{\circ} \mathrm{C}$. The pellet and the supernatant thus obtained contained cellular organelles (microsomal fraction) and the cytosol, respectively. The supernatant was removed, and the pellet was washed with buffer several 
times and resuspended in buffer whose weight was the same as that of the original liver sample. This suspension was put to eppendorf tubes and stored in the freezer at $-80^{\circ} \mathrm{C}$ until the enzymatic assay.

Before the enzymes were assayed, microsomal protein concentrations were assayed by the method according to Lowry (1951). Depending on protein concentrations ascertained, necessary amounts of suspension were taken for the quantification of cytochrome P450 and the determination of EROD activity.

Visible light spectrophotometry (at $390-490 \mathrm{~nm}$ wavelength) was used to determine the total quantity of cytochrome P450. Measurements were made after cytochrome reduction by sodium dithionite and after the complex with carbon monoxide was formed with the maximum at $450 \mathrm{~nm}$ (hence cytochrome P450). 200 - $250 \mu 1$ of suspension (depending on the sample protein content) were added to $7 \mathrm{ml}$ of phosphate buffer. Then a few crystals of dithionite were added, and the solution was stirred and poured to two $3.5 \mathrm{ml}$ glass cells. One of them was used as a standard used in measurements at the above wavelengths. The other cell was bubbled with carbon monoxide for 20 seconds.

The EROD enzyme activity was measured by a spectrofluorimeter. In the presence of NADPH, EROD enzyme activity converts the substrate ethoxyresorufin to resorufin, which is a fluorescent product (Chang and Wax man 1998; Nils en et al. 1998). Standard phosphate buffer, NADPH, and suspension adequate for $0.2 \mathrm{mg} \cdot \mathrm{ml}^{-1} \mathrm{protein}$ were put to a cell. Ethoxyresorufin was then added and the increase in fluorescence was recorded for 5 min (excitation/emission wavelengths setting was $535 / 585 \mathrm{~nm}$ ). EROD activity was subsequently calculated based on a comparison with fluorescence of the standard (resorufin) of known concentration (Rutten et al. 1992).

Analysis of PCB in muscle samples

Composite chub muscle tissue samples from different locations were analyzed. Chub muscle samples were analysed for the content of 7 indicator PCB congeners (IUPAC Nos. 28, 52, 101, 118, 138, 153 and 180). Homogenized samples were desiccated by anhydrous sodium sulphate and the flowing powder was extracted by hexane-dichloromethane solvent mixture $(1: 1, \mathrm{v} / \mathrm{v})$ in a Soxhlet apparatus. Removing of co-extracted lipids from crude extract was accomplished by gel permeation chromatography (GPC) employing BioBeads S-X3 and chloroform as the mobile phase. After solvent evaporation from GPC fraction and dissolving the residue in isooctane, quantification of target analytes was carried out by high-resolution two-dimensional gas chromatography (two capillaries operated in parallel) employing two electron capture detectors (HRGC/2xECD). Limits of quantification (LOQ $-\mu \mathrm{g} . \mathrm{kg}^{-1}$ lipids) for fish are: PCB $28-0.5$, PCB $52-0.6$, PCB $101-1.0$, PCB 118 -0.6, PCB 138 - 1.0, PCB 153 -0.6, PCB 180 - 0.7 (Hajšlová et al. 1997).

Analysis of 1-hydroxypyrene (1-OHPY) in bile samples

1-OHPY was determined by reverse phase HPLC with fluorescence detection after a release of 1-OHPY from conjugates by enzymatic hydrolysis: $25 \mu \mathrm{l}$ of fish bile were dissolved in $9 \mathrm{ml}$ of acetate buffer $(0.1 \mathrm{M}$; $\mathrm{pH} 5)$. After addition of $5 \mu \mathrm{l}$ of $\beta$-glucuronidase/arylsulphatase solution, the mixture was shaken during incubation for 1 hour at $37^{\circ} \mathrm{C}$. Prior to sample loading, a LiChrolut ${ }^{\mathbb{R}} \mathrm{EN} \mathrm{SPE}$ cartridge (200 mg, Merck, Germany) was conditioned with $5 \mathrm{ml}$ of acetone followed by $5 \mathrm{ml}$ of acetate buffer $(0.1 \mathrm{M}$; pH 5). Nine $\mathrm{ml}$ of hydrolysed sample was loaded onto the cartridge at flow rate of $2 \mathrm{ml} \cdot \mathrm{min}^{-1}$, while a slight vacuum was applied at its outlet. The cartridge was subsequently washed with $5 \mathrm{ml}$ of distilled water and then dried 1 minute in an air stream. 1-OHPY was eluted with $8 \mathrm{ml}$ of acetone. The solvent was evaporated at $40^{\circ} \mathrm{C}$ on a rotary vacuum evaporator to dryness. The residue was dissolved in $1 \mathrm{ml}$ of methanol. HPLC determination of 1-OHPY was accomplished on a C18e reverse-phase LiChroCART 205-4 column (LiChrospher ${ }^{\circledR} 100$ RP-18e, $5 \mu \mathrm{m}$ ) with a LiChroCART 4 - 4 guard column (Merck, Germany). Column temperature was held at $45^{\circ} \mathrm{C}$. The flow rate of the mobile phase was $1 \mathrm{ml} \cdot \mathrm{min}^{-1}$. The gradient of the mobile phase was as follows: $1 \mathrm{~min}$ of methanol-water $(75: 25, \mathrm{v} / \mathrm{v})$; followed by a linear gradient in $8 \mathrm{~min}$ to $100 \%$ methanol and eluted for another $4 \mathrm{~min}$. Detection of 1-OHPY was performed by a programmable fluorescence detector, excitation/emission wavelengths setting was 248/397 nm (Hosnedl et al. 2003).

Analysis of PAH in sediments

Before the assay, sediment samples were freeze-dried to constant weight under reduced pressure and temperature $\left(-20{ }^{\circ} \mathrm{C}<37 \mathrm{~Pa}\right)$. The resulting specimens were then sieved for the $<2 \mathrm{~mm}$ fraction. PAHs were extracted by the hexan/aceton/toluen $(2: 1: 1)$ mixture in a closed container in ultrasound bath for $45 \mathrm{~min}$ at $40{ }^{\circ} \mathrm{C}$ and centrifuged. Supernatant was evaporated to dryness in a flow of nitrogen, dissolved in methanol and introduced to the liquid chromatograph. In volatile PAH assays, the supernatant was not evaporated to dryness but concentrated in the 1,2butandiol and isopropanol mixture.

For the sample analysis, a liquid chromatograph with a fluorescence detector and an integration device for signal evaluation was used. PAHs were identified by comparing retention times against the standard, and by analyzing the spectra of individual peaks. The PAHs assayed were fluorene, naphtalene, acenaphtyphene, fenanthrene, anthracene, fluoranthene, pyrene, benzo(a)anthracene, chrysene, benzo(b)fluoranthene, benzo(k)fluoranthene, benzo(a)pyrene, indeno(1, 2, 3-c, d)pyrene, benzo(g, h, i)perylene and dibenzo(a,h)anthracene (ISO/FDIS 17993).

\section{Statistics}

Description statistics were computed for all the parameters studied from individual locations and for the entire set. Non-parametric methods were employed on the data because normality was not ascertained in the data. The Mann-Whitney test was used to assess the differences between the loads in individual locations. Spearman's correlation was used to test the dependence between the parameters studied in individual locations and 
along the longitudinal profile. The critical level for the error of the first type for the determination of statistical significance was set at $5 \%$.

\section{Results}

Cytochrome P450 content and EROD activity

Cytochrome $\mathrm{P} 450$ activity was assayed in the liver of chub captured in six locations along the Vltava and the Elbe. Technical difficulties made it impossible to perform the assay in the rest of the locations. Results are given in Fig. 2. The highest cytochrome P450 median values (given here in $\mathrm{nmol} \cdot \mathrm{mg}^{-1}$ of microsomal protein) were found in samples from Lysá nad Labem (0.48), Hřensko (0.36) and Zelčín (0.31). Values found in Lysá and Hřensko were significantly higher $(\mathrm{p}<0.05)$ than those ascertained in Verdek, Němčice and Děčín.

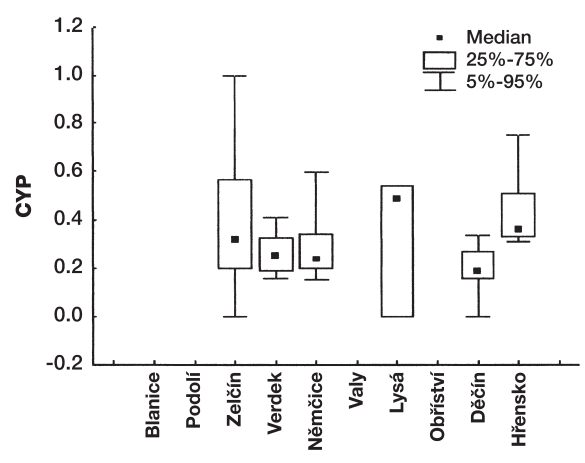

Fig. 2. Levels of cytochrome P450 in chub liver samples from six locations of the River Elbe basin $\left(\mathrm{nmol} \cdot \mathrm{mg}^{-1}\right.$ of microsomal protein)

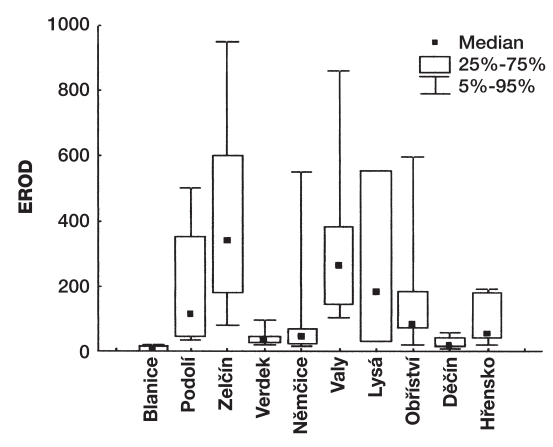

Fig. 3. EROD activity in chub liver samples from all 10 locations of the River Elbe basin ( $\mathrm{pmol} \cdot \mathrm{min}^{-1} \cdot \mathrm{mg}^{-1}$ of microsomal protein)

Values of EROD activity in chub liver samples from all ten locations along the River Elbe are in Fig. 3. The highest values of the EROD median (given in pmol. $\mathrm{min}^{-1} \cdot \mathrm{mg}^{-1}$ of microsomal protein) were found in Zelčín (341.0), Valy (263.2) and Lysá nad Labem (179.17). EROD activity figures from Blanice (control location) were significantly lower than those from any of the other locations studied $(p<0.05)$. EROD activity values for Fish 3 sample from Blanice and Fish 2 sample from Valy are plotted in Figs 4 a, b. It follows from the diagrams that EROD activity in Valy was higher by an order of magnitude compared with the control.

A comparison between the EROD and the CYP 450 activity along the longitudinal profile of the Elbe showed a significant Spearman's correlation $(\mathrm{r}=0.49)$ at $p<0.05$ level of significance, Fig. 5). A high correlation $(r=0.86)(p<0.05)$ between EROD and CYP 450 parameters was found in Němčice.

\section{Chemical analysis}

Content of PCB (the sum of 7 indicator congeners) in chub muscle tissues is shown in Fig. 6. For PCB assays, composite samples of muscle tissues (one sample from each location) were used. The highest values were found in Obřiství (0.16) Zelčín (0.14), Němčice (0.11) and Děčín (0.11). The values are given in $\mathrm{mg} \cdot \mathrm{kg}^{-1}$ wet weight. In all locations studied along the Vltava and the Elbe, PCB concentrations higher by an order of magnitude were found compared with concentrations ascertained in chub muscle samples from the control location Blanice.

Concentrations of the final PAH metabolite 1-hydroxypyrene in chub bile samples from locations in the Elbe basin are shown in Fig. 7. The highest median values (given in $\mathrm{ng} \cdot \mathrm{ml}^{-1}$ ) were found in chub bile samples from Děčín (881.25) and Zelčín (825.40). High values of 


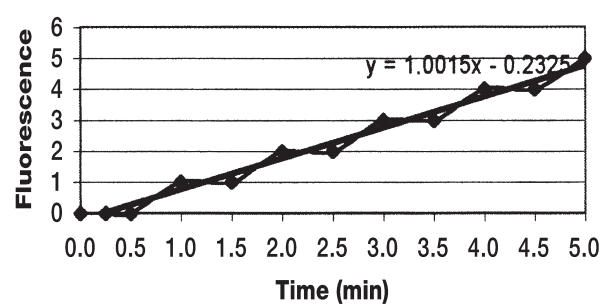

Fig. 4a. EROD activity diagram (Blanice, fish No. 3)

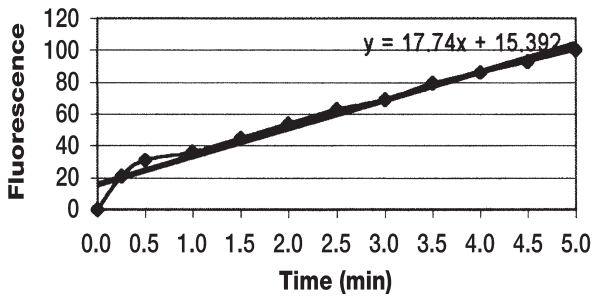

Fig. 4b. EROD activity diagram (Valy at the River Elbe, fish No. 2)

1-OHPY were also found in the control location Blanice (802.23). Values found in Děčín were significantly higher $(p<0.05)$ than those ascertained in Podolí, Valy and Obříství.

PAH concentrations in bottom sediments in locations in the Elbe basin are given in Fig. 8. In each location, only one composite sample was collected. The highest values were found in Hřensko (14.172), Verdek (4.744) and Zelčín (3.686). The values are given in $\mathrm{mg} \cdot \mathrm{kg}^{-1}$ dry weight of bottom sediment.

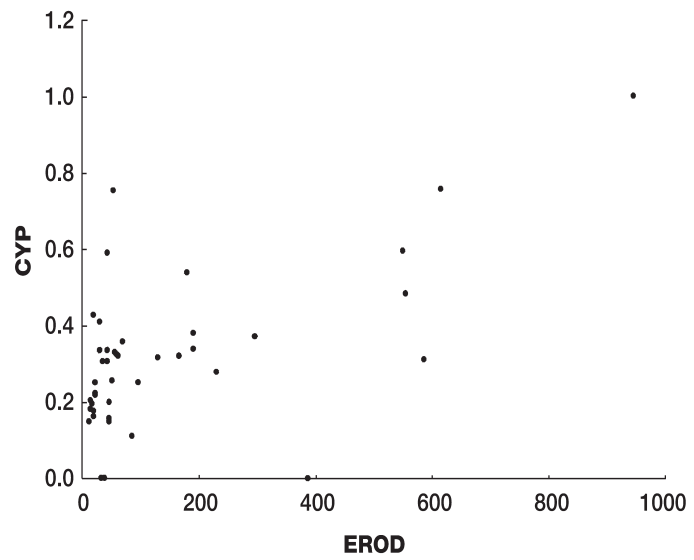

Fig. 5. Correlations between EROD $\left(\mathrm{pmol} \cdot \mathrm{min}^{-1} \cdot \mathrm{mg}^{-1}\right.$ of microsomal protein) and cytochrome P450 (nmol $\cdot \mathrm{mg}^{-1}$ of microsomal protein) parameters in chub liver samples from individual locations in the River Elbe basin

\section{Discussion}

Moderately elevated levels in the chub liver were established by authors for CYP 450 values above $0.150 \mathrm{nmol} \cdot \mathrm{mg}^{-1}$ microsomal protein, and EROD activity in excess of $25 \mathrm{pmol} \cdot \mathrm{min}^{-1} \cdot \mathrm{mg}^{-1}$ microsomal protein; high levels for CYP 450 values above $300 \mathrm{nmol} \cdot \mathrm{mg}^{-1}$ microsomal protein and EROD activity in excess of $250 \mathrm{pmol} \cdot \mathrm{min}^{-1} \cdot \mathrm{mg}^{-1}$ microsomal protein (Sleiderink et al. 1995; Machala et al. 2000; Solé et al. 2003; Miller et al. 2004; Parente et al. 2004; Rodriguez-C ea et al. 2004). However, because literary data often diverge, the above figures should only be considered as approximate. It follows from a comparison between the data produced in our study and the above approximate figures that CYP 450 and EROD activating substances were present in all the locations studied in the River Elbe basin.

CYP 450 and EROD activity levels found in chub liver samples were correlated with results of chemical monitoring, specifically with $\mathrm{PCB}$ concentrations in chub muscle tissue samples, PAH levels in bottom sediments and 1-OHPY levels in chub bile samples. Correlations between EROD, CYP 450 and PCB were computed against EROD and CYP 
Contenst of PCBs in chub liver samples

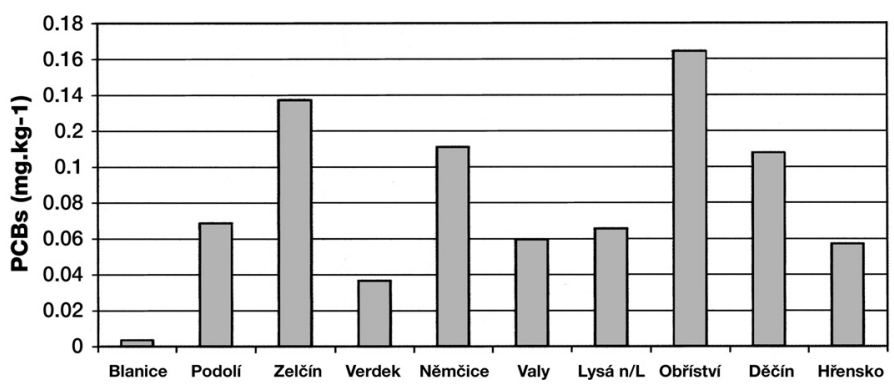

Fig. 6. Content of PCB (sum of 7 indicator congeners) in chub muscle samples (wet weight) from different locations of the River Elbe basin

450 means $\left(\mathrm{r}_{\mathrm{EROD}}=0.47, \mathrm{r}_{\mathrm{CYP}}=0.09\right)$ and their medians $\left(\mathrm{r}_{\mathrm{EROD}}=0.41, \mathrm{r}_{\mathrm{CYP}}=0.26\right)$. None of these correlations nor the correlation between EROD (median) and PAH in sediments ( $\mathrm{r}=$ - 0.43) were, however, statistically significant. For the computations, the non-parametric Spearman's correlation was employed. Results of the test depend not only on the magnitude of the correlation coefficient but also on the number of values correlated. In the case of PCB in muscle tissue samples and PAH in sediments, only one value per location was correlated (composite samples were used). Although correlation coefficients 0.47 and 0.41 for PCB and EROD respectively are relatively high, it is impossible to rule out that the results were only accidental in view of the limited volume of data produced by the analysis of a relatively small set of PCB and PAH contamination samples. It is noted in the final results that the correlation is not statistically significant.

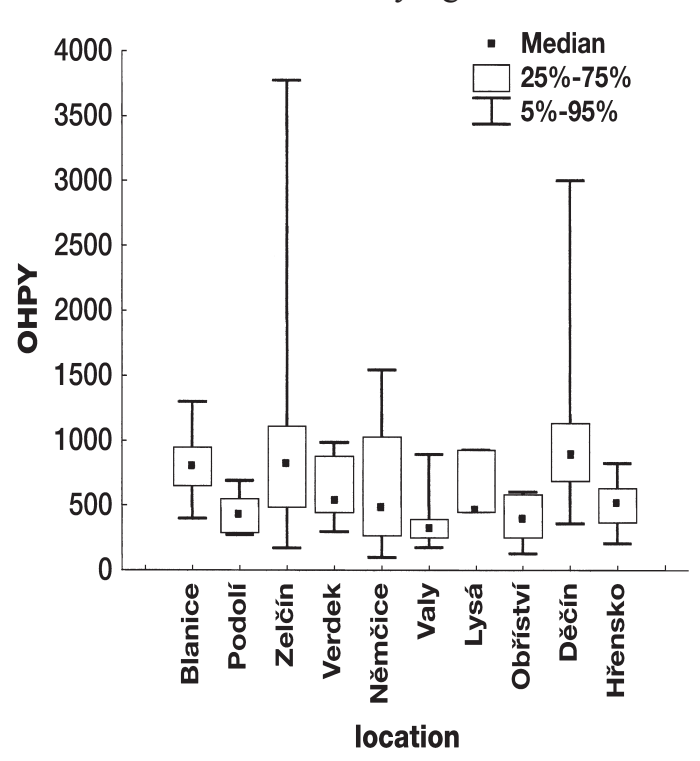

With regard to PAHs in sediments, their levels can be used for the assessment of long-term load of the aquatic environment. The biological availability of PAHs immobilized in sediments may, however, be very low and any interpretations regarding their toxicity for the biotic component are rather dubious. Only very low correlations between PAH findings in the fish affected and the abiotic components of their environment were regularly found not only under laboratory but particularly under field conditions (Verweij et al. 2004; Vives et al. 2004). PAH levels in the organism of fish are very low because they are relatively rapidly metabolized (Meador et al. 1995). The fact that no significant correlation between the $\mathrm{PAH}$ content in bottom sediments and its

Fig. 7. Content of 1-OHPY $\left(\mathrm{ng} \cdot \mathrm{ml}^{-1}\right)$ in chub bile samples from different locations of the River Elbe basin effects on the organism of chubs were found in the present field study is in 


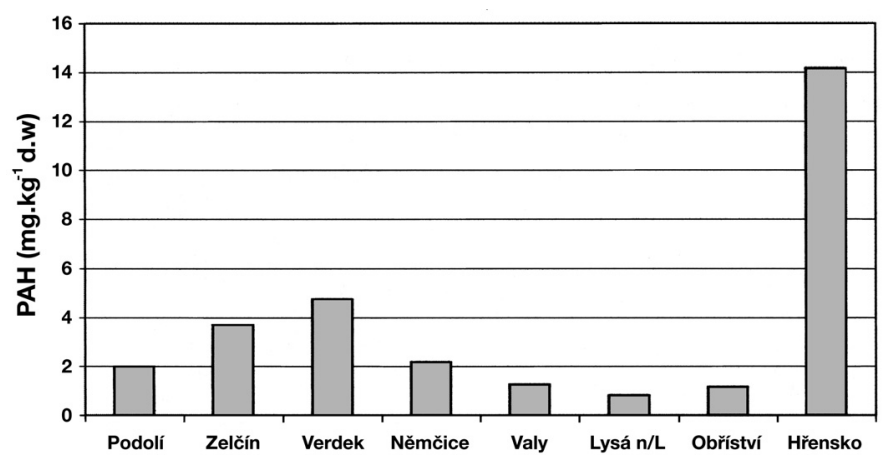

Fig. 8. Content of PAH (sum of 15 PAHs - EPA list, see chapter 2.5) in sediments (dry weight) from different locations of the River Elbe basin (control location Blanice had levels under the limit of detection)

agreement with the above reports. For the quantification of the effects, activity of enzymes of the first phase of detoxification (CYP 450 and EROD) was used.

For practical reasons, the biota exposure to toxic effects of $\mathrm{PAH}$ in aquatic ecosystems is based on the monitoring of levels of terminal metabolites. The most frequently used one is 1-hydroxypyrene. Its presence in bile is indicative of the PAH metabolic conversion in the organism (V a e s s en et al. 1986). 1-hydroxypyrene can be detected with high sensitivity and good selectivity by means of the fluorimetric detector (Van Rooij et al. 1994; Hosnedl et al 2003). For the assessment of the Elbe basin contamination, 1-OHPY was used, and the results obtained were correlated with the activity of enzymes of the first phase of detoxification, i.e. EROD. No significant correlation was found between contamination (indicator 1-OHPY) and its effect (indicator EROD) $(\mathrm{r}=-0.37)$.

Very non-standard results were obtained in the control location of Blanice. PAH values in sediments were below limits of detection. Levels of 1-OHPY in chub bile were, however, relatively high. The median of EROD activity in the chub liver was 6.13 pmol.mg-1. $\mathrm{min}^{-1}$, which is a value just above the determinability limit. It is rather difficult to explain these outof-the-way results. The fact that PAH levels in sediments were below the limit of detection can be ascribed to the gravel-and-sand character of the river Blanice bottom with a low proportion of the organic component capable of binding PAHs. The high level of 1-OHPY in the bile and the low activity of the detoxification enzyme EROD in the liver may suggest an acute contamination. When samples were collected, the volume of the final metabolite in the bile was still high, while the EROD enzyme activity still remained at a low level. The induction of CYP 450 and EROD in the liver is characterized by several days' latency (Lew is 2001).

The assessment of the river Elbe basin contamination failed to produce an unambiguous proof of correlations between the activity of detoxification enzymes (CYP 450 and EROD) in the liver and their two important inducers (PCBs and PAHs). The assessment of the river Vltava contamination, however, showed that the most seriously affected location was Zelčín (downstream of the Prague conurbation). In that location elevated EROD, PCB, 1-OHPY and $\mathrm{PAH}$ values were demonstrated in the liver, muscle tissues, bile and bottom sediments, respectively. The highest EROD levels in the chub liver from the Elbe were found in Valy, Lysá nad Labem and Obřiství, in spite of the fact that PAH, 1-OHPY and PCB levels in those locations were not among the markedly highest ones. Those locations (i.e. Valy and Obříství) are massively contaminated by industrial wastewater from local sources. Besides the pollutants studied, a number of other substances activating detoxification enzymes were found there. The impact on fish populations in those locations (particularly in Obřiství and Lysá nad 
Labem) is also documented by our failure to capture the sufficient number of chub there. Moreover, the fish captured there exhibited serious pathological changes that were found in almost all of the fish during both the macroscopic and histological examinations of their health. In Hřensko, on the other hand, the highest PCB and PAH levels were found in muscle tissues and bottom sediments, respectively, while EROD levels were relatively low. In some instances, however, the presence of PAH or PCB may not induce elevated CYP1A levels. This indicates either high concentrations of pollutants (Stegeman et al. 1997; Schlezinger and Stegeman 2001; Wirgin and Theodorakis 2002), or the presence of contaminants specifically inhibiting cytochrome P450 (e.g. $\mathrm{Cu}, \mathrm{Zn}, \mathrm{Pb}, \mathrm{Cd}$ or Ni).

The results obtained in the river Elbe document the importance of biochemical markers for the assessment of surface water contamination levels. For the evaluation of aquatic environment contamination with xenobiotic substances, EROD values are particularly useful.

\section{Využití biochemických markerů k posouzení kontaminace řeky Labe organickými polutanty}

Cílem práce bylo pomocí vybraných biochemických markerů posoudit kontaminaci povodí řeky Labe. Jako biochemické markery byly použity enzymy první fáze přeměny xenobiotik, a to cytochrom P450 (CYP 450) a ethoxyresorufin-O-deethyláza (EROD). Výsledky byly korelovány s nejdůležitějšími induktory těchto enzymů, a to s hodnotami PCB ve svalovině ryb, s hodnotami PAH v sedimentech dna a s hodnotami 1-hydroxypyrenu (1-OHPY) ve žluči ryb (terminální metabolit PAH, resp. jednoho z nich - pyrenu), které byly stanoveny v rámci chemického monitoringu povodí řeky Labe. Jako indikátorový druh byl použit jelec tloušt (Leuciscus cephalus L.), který byl odloven na deseti lokalitách povodí řeky Labe. Při porovnání aktivity EROD a CYP $450 \mathrm{v}$ podélném profilu povodí řeky Labe byla nalezena významná korelace na hladině významnosti $p<0.05$. Nejvyšší aktivity EROD v játrech byly naměřeny v lokalitách Zelčín (341 $\left.\mathrm{pmol} \cdot \mathrm{min}^{-1} \cdot \mathrm{mg}^{-1}\right)$, Valy $(263.2$ $\left.\mathrm{pmol} \cdot \mathrm{min}^{-1} \cdot \mathrm{mg}^{-1}\right)$ a Lysá nad Labem $\left(179.17 \mathrm{pmol} \cdot \mathrm{min}^{-1} \cdot \mathrm{mg}^{-1}\right)$. V kontrolní lokalitě Blanice byla aktivita EROD významně nižší oproti všem sledovaným lokalitám $(p<0.05)$. Nepodařilo se jednoznačně prokázat korelace mezi aktivitou detoxifikačních enzymů (CYP 450 a EROD) v játrech a jejich dvěma významnými induktory (PCB a PAH). Diskutovány jsou možnosti účinku dalších látek způsobujících aktivaci nebo inhibici detoxifikačních enzymů.

\section{Acknowledgements}

This study was supported by the USB RIFCH No. MSM6007665809 and the Ministry of the Environment of the Czech Republic VaV/650/5/03.

\section{References}

BARUŠ, V, OLIVA, O, et al. 1995: Mihulovci a ryby (2). Academia, Praha, 698 p. (In Czech)

BLAŽKOVÁ, Š, NESMĚRÁK, I, NOVICKÝ, O (Eds.) 1998: Elbe Project II. T. G. M. Water Research Institute, Prague, $55 \mathrm{p}$.

BLAŽKOVÁ, Š (Ed.) 2002: Elbe Project III. Research on the Czech reach of the Elbe River. T. G. M. Water Research Institute, Prague, $63 \mathrm{p}$.

BILLIARD, SM, HAHN, ME, FRANKS, DG, PETERSON, RE, BOLS, NC, HODSON, PV 2002: Binding of polycyclic aromatic hydrocarbons (PAHs) to teleost aryl hydrocarbon receptors (AHRs). Comp Biochem Physiol Pt B 133: 55-68

BRAMMELL, BF, PRICE, DJ, BIRGE, WJ, ELSKUS, AA 2004: Apparent lack of CYP1A response to high PCb body burdens in fish from a chronically contaminated PCB site. Mar Environ Res 58: 251-255

CARLSON, EA, LI, Y, ZELIKOFF, JT 2004: Benzo[a]pyrene-induced immunotoxicity in Japanese medaka (Oryzias latipes): relationship between lymphoid CYP1A activity and humoral immune suppression. Toxicol Appl Pharmacol 15: 40-52

CHANG, TKH, WAXMAN, DJ 1998: Enzymatic analysis of cDNA-expressed human CYP1A1, CYP1A2, and CYP1B1 with 7-ethoxyresorufin as a substrate. In: PHILLIPS, IR, SHEPHARD, EA (Eds.): Methods in molecular biology, Vol. 107: Cytochrome P450 protocols. Humana press Inc., Totowa, NJ, pp. 103-109 
ELSKUS, AA 2004: Estradiol and estriol suppress CYP1A expression in rainbow trout primary hepatocytes. Mar Environ Res 58: 463-467

HAJ-LOVA, J, SCHOULA, R, KOCOUREK, V, HOLADOVA, K, POUSTKA, J, KOHOUTKOVA, J, SVOBODOVA, Z 1997: Polychlorinated biphenyls and other persistent chlorinated contaminants in fish as indicators of pollution of aquatic ecosystem in Czech Republic. Toxicol Environ Chem 59: 279-291

HOSNEDL, T, HAJ·LOVÁ, J, KOCOUREK, V, TOMANIOVÁ, M, VOLKA, K 2003: 1-Hydroxypyrene as a biomarker for fish exposure to polycyclic aromatic hydrocarbons. Bull Environ Contam Toxicol 71: 465-472

JUNG, DK, KLAUS, T, FENT, K 2001: Cytochrome P450 induction by nitrated polycyclic aromatic hydrocarbons, azaarenes, and binary mixtures in fish hepatoma cell line PLHC-1. Environ Toxicol Chem 20: 149-159

LEWIS, DFV 2001: Guide to cytochromes P450 structure and function. Taylor \& Francis Inc., London, 215 p.

LEWIS, DFV, IOANNIDES, C, PARKE, DV 2003: A quantitative structure-activity relationship (QSAR) study of mutagenicity in several series of organic chemicals likely to be activated by cytochrome P450 enzymes. Teratogen Carcin Mut, Suppl 1:187-93

LOWRY, OH, ROSEBROUGH, NJ, FARR, AL, RANDALL, RJ 1951: Protein measurement with folin phenol reagent. J Biol Chem 193: 265-275

MACHALA, M, NEZVEDA, K, PETŘIVALSKÝ, M, JAROŠOVÁ, A, PIAČKA, V, SVOBODOVÁ, Z 1997: Monooxygenase activities in carp as biochemical markers of pollution by polycyclic and polyhalogenated aromatic hydrocarbons: choice of substrates and effects of temperature, gender and capture stress. Aquat Toxicol 37: 113-123

MACHALA, M, ULRICH, R, NEČA, J, VYKUSOVÁ, B, KOLÁŘOVÁ, J, MÁCHOVÁ, J, SVOBODOVÁ, Z 2000: Biochemical monitoring of aquatic pollution: Indicators of dioxin-like toxicity and oxidative stress in the roach (Rutilus rutilus) and chub (Leuciscus cephalus) in the Skalice river. Vet Med-Czech 45: 55-60

MCARDLE, ME, MCELROY, AE, ELSKUS, AA 2004: Enzymatic and estrogenic responses in fish exposed to organic pollutants in the New York - New Jersey (USA) harbor complex. Environ Toxicol Chem 23: 953-959

MEADOR, JP, CASILLAS, E, SLOAN, CA, VARANASI, U 1995: Comparative bioaccumulation of polycyclic aromatic-hydrocarbons from sediment by 2 infaunal invertebrates. Mar Ecol-Progr Ser 123: 107-124

MILLER, KA, ADDISON, RF, BANDIERA, SM 2004: Hepatic CYP1A levels and EROD activity in English sole: biomonitoring of marine contaminants in Vancouver Harbour. Mar Environ Res 57: 37-54

NESMĚRÁK, I (Ed.) 1994: Elbe Project. Summary of results from the period 1991-1993. T. G. M. Water Research Institute, Prague, $47 \mathrm{p}$.

NILSEN, BM, BERG, K, GOKS_YR, A 1998: Induction of cytochrome P450 1A (CYP1A) in fish. In: PHILLIPS, IR, SHEPHARD, EA (Eds.): Methods in molecular biology, Vol. 107: Cytochrome P450 protocols. Humana press Inc., Totowa, NJ, pp. 423-438

PARENTE, TEM, DE-OLIVIERA, ACAX, SILVA, IB, ARAUJO, FG, PAUMGARTTEN, FJR 2003: Induced alkoxyresorufin-O-dealkylases in tilapias (Oreochromis niloticus) from Guandu river, Rio de Janeiro, Brazil. Chemosphere 54: 1613-1618

RODRIGUEZ-CEA, A, DEL ROSARIO FERNANDEZ DE LA CAMPA, M, SANZ-MEDEL, A 2004: Brown trout as a sentinel organism for organic pollution in the field using catalytic and immunochemical assays of cytochrome P-450 1A. J Environ Monit 6: 368-73

RUTTEN, AA, FALKE, HE, CATSBURG, JF, WORTELBOER, HM, BLAAUBOER, BJ, DOORN, L, VAN LEEUWEN, FX, THEELEN, R, RIETJENS, IM 1992: Interlaboratory comparison of microsomal ethoxyresorufin and pentoxyresorufin O-dealkylation determinations: standardization of assay conditions. Arch Toxicol 66: 237-44

SCHLENK, D, DI GIULIO, RT 2002: Biochemical responses as indicators of aquatic ecosystem health. In: MARSHALL ADAMS, S (Ed.): Biological indicators of aquatic ecosystem stress. AFS, Bethesda, pp. 14-17

SCHLEZINGER, JJ, STEGEMAN, JJ 2001: Induction and suppression of cytochrome P450 1A by 3,3‘,4,4`,5pentachlorobiphenyl and its relationship to oxidative stress in the marine fish scup (Stenotomus chrysops). Aquat Toxicol 52: 101-115

SLEIDERINK, HM, OOSTING, I, GOKS $\varnothing Y$ R, A, BOON, JP 1995: Sensitivity of cytochrome P450 1A induction in dab (Limanda limanda) of different age and sex as a biomarker for environmental contaminants in the southern North Sea. Arch Environ Contam Toxicol 28: 423-430

SOLÉ, M, RALDUA, D, PIFERRER, F, BARCELÓ, D, PORTE, C 2004: Feminisation of wild carp, Cyprinus carpio, in a polluted environment: plasma steroid hormones, gonadal morphology and xenobiotic metabolizing system. Comp Biochem Physiol Pt C 136: 145-156

STEGEMAN, JJ, LECH, JJ 1991: Cytochrome P-450 monooxygenase systems in aquatic species: carcinogen metabolism and biomarkers for carcinogen and pollutant exposure. Environ Health Perspect 90: 101-9

STEGEMAN, JJ, WOODIN, BR, SINGH H, OLEKSIAK, MF, CELANDER M 1997: Cytochromes P450 (CYP) in tropical fishes: catalytic activities, expression of multiple CYP proteins and high levels of microsomal P450 in liver of fishes from Bermuda. Comp Biochem Physiol Pt C 116: 61-75

VAESSEN, HAMG, JEKEL, AA, WILBERS, AAMM 1986: Dietary intake of polycyclic aromatic hydrocarbon. In: PAU symposium, Nijmegen

VAN ROOIJ, JGM, VEEGER, MMS, BODELIER-BADE, MM, SCHEEPERS, PTJ, JONGENEELEN, FJ 1994: Smoking and dietary-intake of polycyclic aromatic-hydrocarbons as sources of interindividual variability in the base-line excretion of 1-hydroxypyrene in urine. Int Arch Occup Envir Health 66: 55-65 
VERWEIJ, F, BOOIJ, K, SATUMALAY, K, VAN DER MOLEN, N, VAN DER OOST, R 2004: Assessment of bioavailable PAH, PCB and OCP concentrations in water, using semipermeable membrane devices (SPMDs), sediments and caged carp. Chemosphere 54: 1675-1689

VIVES, I, GRIMALT, JO, FERNÁNDEZ, P, ROSSELAND, B 2004: Polycyclic aromatic hydrocarbons in fish from remote and high mountain lakes in Europe and Greenland. Sci Total Envir 324: 67-77

WHITE, RD, SHEA, D, STEGEMAN, JJ 1997: Metabolism of the aryl hydrocarbon receptor agonist 3,3,4,4`tetrachlorobiphenyl by the marine fish scup (Stenotomus chrysops) in vivo and in vitro. Drug Metab Disposition 25: 564-572

WIRGIN, II, THEODORAKIS, CV 2002: Molecular biomarkers in aquatic organisms. In: MARSHALL ADAMS, $\mathrm{S}$ (Ed.): Biological indicators of aquatic ecosystem stress, AFS, Bethesda, pp. 73-82

ISO/FDIS 17993 Water quality - Determination of 15 polycyclic aromatic hydrocarbons (PAH) in water by HPLC with fluorescence detection. 